\title{
The effect of elevated progesterone and pregnancy status on mRNA expression and localisation of progesterone and oestrogen receptors in the bovine uterus
}

\author{
L A Okumu, N Forde, A G Fahey, E Fitzpatrick, J F Roche, M A Crowe and P Lonergan \\ School of Agriculture, Food Science and Veterinary Medicine, University College Dublin, Belfield, Dublin 4, Ireland \\ Correspondence should be addressed to P Lonergan; Email: pat.lonergan@ucd.ie
}

\begin{abstract}
To investigate the effects of pregnancy or post-ovulatory progesterone $\left(\mathbf{P}_{4}\right)$ supplementation on the expression of oestrogen and $\mathbf{P}_{4}$ receptors (ESRs and PGRs) in the bovine uterus, heifers $(n=263)$ were randomly assigned to the following treatments: $i)$ cyclic, normal $P_{4}$; ii) cyclic, high $P_{4}$; iii) pregnant, normal $P_{4}$; and iv) pregnant, high $P_{4}$ on days 5, 7, 13 and 16 of pregnancy/oestrous cycle. Elevated $P_{4}$ was achieved through $P_{4}$-releasing intravaginal device insertion on day 3 after oestrus, resulting in increased concentrations from day 3.5 to $8(P<0.05)$ in the high groups than in the normal groups. Irrespective of treatment, $P G R$ and ESR1 mRNA expressions were highest on days 5 and 7 and decreased on day $13(P<0.05)$, while ESR 2 mRNA expression increased on day $7(P<0.05)$ and similar levels were maintained within the normal $P_{4}$ groups subsequently. Expression in the high $P_{4}$ groups decreased on day $13(P<0.05)$. $P G R-A B$ and PGR-B protein expressions were high in the luminal and superficial glands on days 5 and 7 , but by day 13 , expression had declined to very low or undetectable levels and high $\mathrm{P}_{4}$ concentration tended to decrease or decreased significantly $(P<0.05)$ the expression in these regions on days 5 and 7 . ESR1 protein expression was high, with no treatment effect. ESR2 protein was also highly expressed, with no clear effect of treatment. In conclusion, early post-ovulatory $P_{4}$ supplementation advances the disappearance of PGR protein from the luminal epithelium on days 5 and 7, and decreases ESR2 mRNA expression during the mid-luteal phase, but has no effect on PGR or ESR1 mRNA expression.

Reproduction (2010) 140 143-153
\end{abstract}

\section{Introduction}

Reproductive tract and behavioural changes during the oestrous cycle of cattle are to a large extent governed by follicular oestradiol $\left(E_{2}\right)$ and luteal progesterone $\left(\mathrm{P}_{4}\right)$ concentrations (Kimmins \& MacLaren 2001). Conceptus growth and development require the action of $\mathrm{P}_{4}$ on the uterus to regulate endometrial function including conceptus-maternal interactions, pregnancy recognition and uterine receptivity for implantation. The genomic effects of these two steroids on the endometrium are mediated primarily by the binding to their nuclear receptors: oestrogen receptor (ESR) and $\mathrm{P}_{4}$ receptor (PGR) respectively, which are located within the target cells in the uterus (Ing \& Tornesi 1997). Both belong to a superfamily of nuclear receptors that include not only steroid receptors but also vitamin D, thyroid hormone and orphan receptors (Carson-Jurica et al. 1990, Tsai \& O'Malley 1994). The basic structure of these receptors consists of a C-terminal or ligand-binding domain, a highly conserved DNA-binding domain and an $\mathrm{N}$-terminal domain of variable length (Stormshak \& Bishop 2008).
Oestrogen enhances the expression of its own receptors as well as those for $\mathrm{P}_{4}$ (Spencer \& Bazer 1995, Wathes et al. 1996, Ing \& Tornesi 1997), and functions at the cellular level to increase the rate of mitosis, tissue oedema and number of immune cells such as neutrophils and macrophages in the uterus (De \& Wood 1990, Kachkache et al. 1991, Tibbetts et al. 1999). $\mathrm{P}_{4}$ is essential for ensuring a favourable uterine environment and maintaining pregnancy (Spencer et al. 2008, Forde et al. 2009). Contrary to the actions of oestrogen, $\mathrm{P}_{4}$ is inhibitory to the expression of ESRs, and negatively regulates the expression of its own receptors during the mid-luteal phase of the oestrous cycle and during early pregnancy (Spencer \& Bazer 1995, Spencer et al. 1995).

$E_{2}$ mediates its functions through the $\alpha$-form (ESR1) and $\beta$-form (ESR2) of its receptors (D'Haeseleer et al. 2006). These forms differ in the $\mathrm{N}$-terminal transactivation domain and in the C-terminal ligand-binding domain (Kuiper et al. 1997). ESR1 protein is expressed in the pituitary gland, ovary, uterus, testis, epididymis and adrenal gland (Kuiper et al. 1997), while ESR2 
protein is mainly expressed in the ovary and the prostate (Kuiper et al. 1996, 1997, Enmark et al. 1997). $\mathrm{P}_{4}$ mediates its genomic functions mainly through two kinds of nuclear receptors: PGR isoform A (PGR-A), which is N-terminally truncated (missing 164 amino acids), and PGR isoform B (PGR-B). Both isoforms are encoded by the same gene, but are regulated by different promoters (Mote et al. 2006). In different species, the two PGRs may function either individually as homodimers, e.g. in rodents (Mulac-Jericevic \& Conneely 2004, Mote et al. 2006), or as a heterodimer, as is found in humans (Arnett-Mansfield et al. 2004). PGR-A plays a major role in mediating the actions of $\mathrm{P}_{4}$ in the uterus and ovary, while PGR-B is more important in mammary gland development (Mulac-Jericevic et al. 2000, 2003).

$\mathrm{P}_{4}$ is a key hormone that regulates conceptus development in ruminants. Elevated concentrations of $\mathrm{P}_{4}$ in the immediate post-ovulatory period have been shown to significantly alter the pattern of endometrial gene expression by advancing the temporal changes that occur normally as well as by advancing elongation of the conceptus (Garrett et al. 1988, Satterfield et al. 2006, Carter et al. 2008). This effect has been shown to be a consequence of priming of the endometrium, presumably resulting in alterations of the histotroph composition, rather than to be a direct effect on the conceptus (Clemente et al. 2009). In support of this hypothesis, administration of $\mathrm{P}_{4}$ early in the oestrous cycle can advance uterine receptivity for the transfer of older asynchronous embryos (Geisert et al. 1991).

Despite the importance of $\mathrm{P}_{4}$ for the establishment and maintenance of pregnancy in mammals, paradoxically, endometrial epithelia cease expressing PGR prior to implantation in all mammals studied (Bazer et al. 2009). For example, loss of PGR in ovine endometrial luminal, superficial and glandular epithelia occurs by days 11 and 13 of the oestrous cycle and pregnancy respectively, but stromal cells and myometrial cells express PGR throughout gestation. In this study, it is hypothesised that elevated $\mathrm{P}_{4}$ in the early luteal phase will lead to a more rapid decline in $\mathrm{PGR}$ in the uterine luminal epithelium (LE) of cyclic and pregnant heifers. This would lead to an alteration in the timing of expression of $\mathrm{P}_{4}$-regulated genes in the endometrium, which has been shown to advance conceptus elongation (Garrett et al. 1988, Satterfield et al. 2006, Carter et al. 2008). Therefore, the objectives of this study were to determine i) the mRNA expression pattern and protein localisation of the oestrogen and nuclear PGRs in the uterus during different stages of the oestrous cycle; ii) how the expression and localisation patterns are affected by the presence of an embryo/conceptus and iii) if elevated $\mathrm{P}_{4}$, which has been shown to advance conceptus development (Carter et al. 2008), alters the expression and/or localisation of these genes and proteins.

\section{Results}

\section{PGR mRNA expression and protein localisation}

In general, the expression pattern of both steroid receptors was not greatly affected by the presence or absence of a conceptus (i.e. pregnant versus cyclic endometrium), but it was strongly influenced by the day of the oestrous cycle/early pregnancy. In general, irrespective of the treatment group, expression of $P G R$ mRNA was highest on day 5 and declined on subsequent days, with a significant decrease between day 7 and 13 (Fig. $1 ; P<0.05)$. On a given day, the only differences between treatments were observed on day 13 , when $P G R$ mRNA abundance was lower in the pregnant animals than in the cyclic animals, irrespective of $\mathrm{P}_{4}$ status $(P<0.05)$.

Generally, the intensity of staining was greater for the PGR-B isoform than for the PGR-AB isoform. However, both exhibited the same pattern of expression, where the protein intensity declined as the days of pregnancy/oestrous cycle progressed (Figs 2 and 3). In the LE and superficial glands (SGs), protein levels of both PGR isoforms declined to very low or undetectable levels between day 7 and 13 in both pregnant and cyclic heifers, remaining so until day 16 . This decline was significant only in the cyclic and pregnant groups with normal $\mathrm{P}_{4}(P<0.05)$.

Elevated $\mathrm{P}_{4}$ promoted the early downregulation of the PGR on days 5 and 7 compared with normal $\mathrm{P}_{4}$ concentrations. In the presence of elevated $\mathrm{P}_{4}$, irrespective of pregnancy status, the disappearance of both protein isoforms from the LE and SGs was more rapid on days 5 and 7 than in the control animals; for example, animals with high $\mathrm{P}_{4}$ on day 5 had approximately the same protein abundance as those with normal $\mathrm{P}_{4}$ on day 7 (Figs 2 and 3).

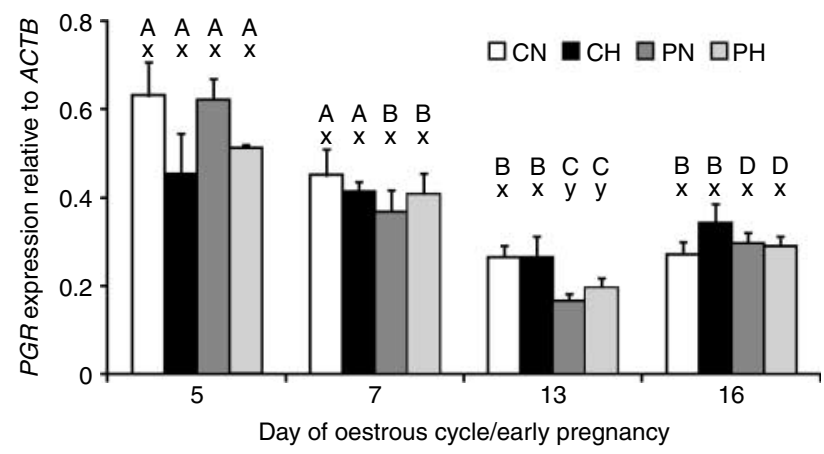

Figure 1 Temporal and spatial expressions of $P G R$ mRNA relative to $A C T B$ (normaliser gene) in bovine endometrium. Expression values are given for cyclic, normal $\mathrm{P}_{4}\left(\mathrm{CN}\right.$; open bars); cyclic, high $\mathrm{P}_{4}(\mathrm{CH}$; closed bars); pregnant, normal $\mathrm{P}_{4}$ ( $\mathrm{PN}$; dotted open bars); and pregnant, high $\mathrm{P}_{4}(\mathrm{PH}$; hatched closed bars) heifers on days 5, 7, 13 and 16 of the oestrous cycle/early pregnancy. Significant differences $(P<0.05)$ in $P G R$ expression within specific treatments between days are denoted by A-D, while significant differences $(P<0.05)$ in $P G R$ expression within each day amongst the treatments are denoted by $\mathrm{x}$ and $\mathrm{y}$. 
A Day 5

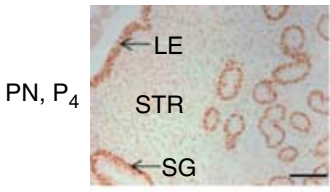

$\mathrm{PH}, \mathrm{P}_{4}$

Negative control

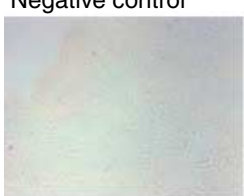

Day 7
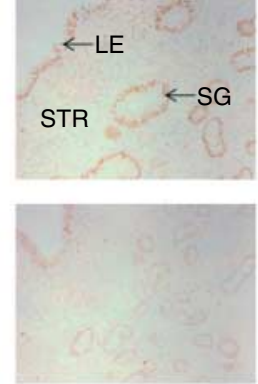

Day 13
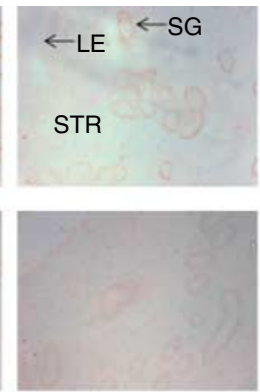

Day 16
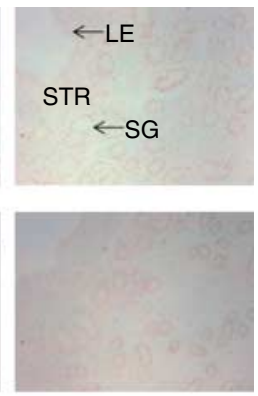
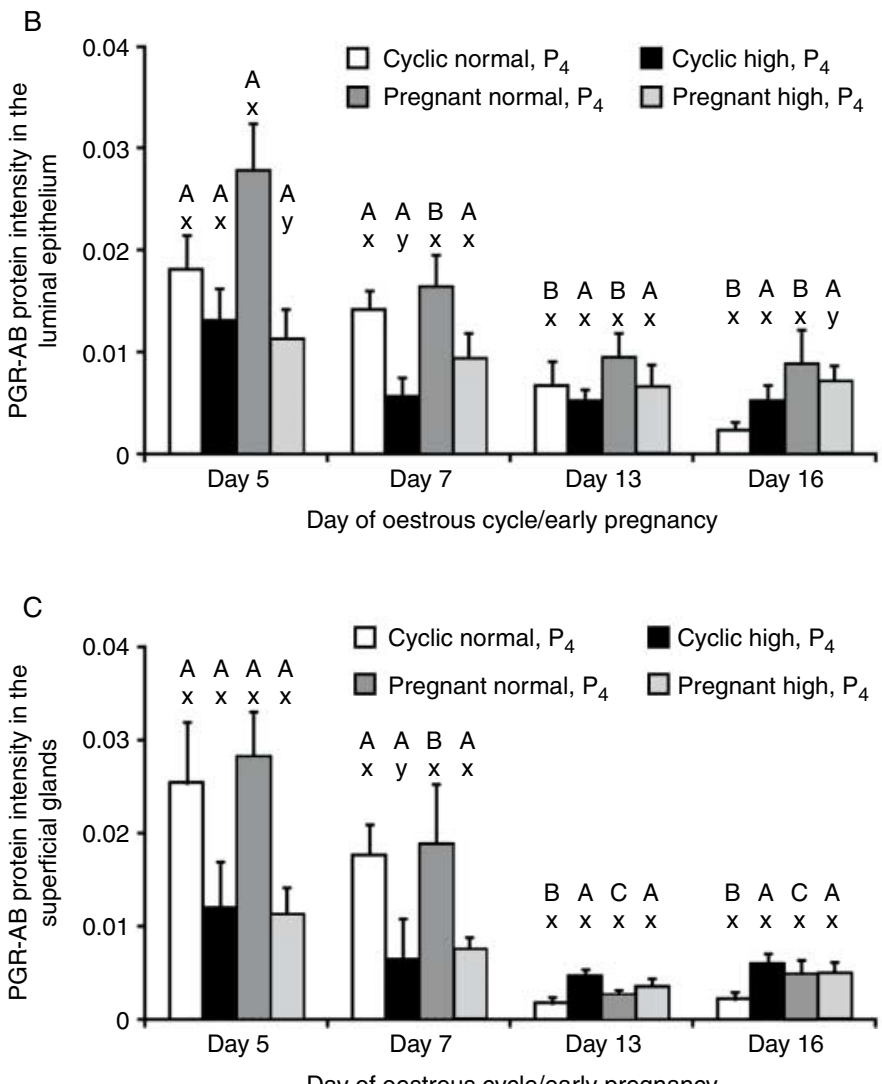

Figure 2 Representative images depicting the localisation of PGR-AB protein (A) in the luminal epithelium (LE), superficial glands (SGs) and stroma (STR) of bovine endometrium on days 5 , 7,13 and 16 in pregnant $(\mathrm{P})$ heifers with normal $(\mathrm{PN})$ or high $(\mathrm{PH}) \mathrm{P}_{4}$. Bar $=100 \mu \mathrm{m}$. Graphical representation of the intensity of $\mathrm{PGR}-\mathrm{AB}$ protein isoform localised within the luminal epithelium (LE; B) or superficial glands (SGs; C) in uterine cross sections of cyclic and pregnant heifers with normal or high $\mathrm{P}_{4}$ on days $5,7,13$ and 16 of the oestrous cycle/early pregnancy. Significant differences $(P<0.05)$ in protein abundance are depicted with different superscripts between treatments within a specific day ( $\mathrm{x}$ and $\mathrm{y})$ and within treatment between days $(\mathrm{A}-\mathrm{C})$.

\section{ESR1 and ESR2 mRNA expression and protein localisation}

Expression of ESR1 mRNA displayed a similar pattern to that of $P G R$, with it being high on days 5 and 7 and lower on day $13(P<0.05)$, and remaining low on day 16 (Fig. 4A). Expression of ESR2 mRNA increased in all treatment groups from day 5 to $7(P<0.05)$. This level of expression was maintained to day 16 in animals with normal $\mathrm{P}_{4}$. In contrast, elevated $\mathrm{P}_{4}$ led to a decrease in expression on day 13 ( $P<0.05$, Fig. 5A).

ESR1 protein was detected in the LE, SGs, deep glands (DGs), myometrium (MYO) and stroma (STR), and was unaffected by day, pregnancy status or $\mathrm{P}_{4}$ concentration $(P>0.05$, Fig. $4 \mathrm{~B})$. The abundance of ESR2 protein was also high in the uterus, with no clear pattern of difference in expression. 
A Day 5

$\mathrm{PN}, \mathrm{P}_{4}$
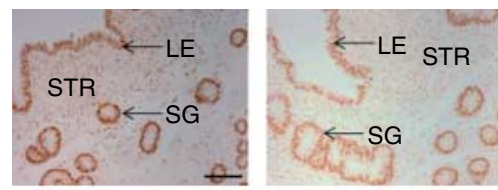

$\mathrm{PH}, \mathrm{P}_{4}$ Negative control

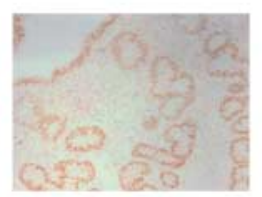

Day 13
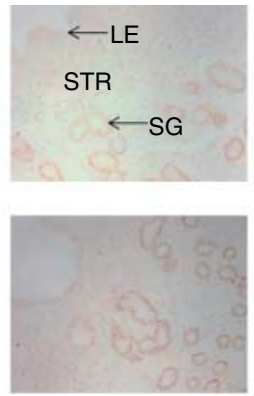

Day 16
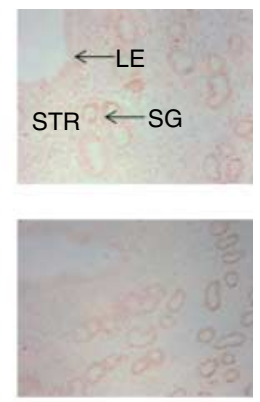

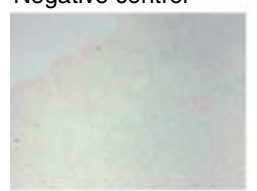

B
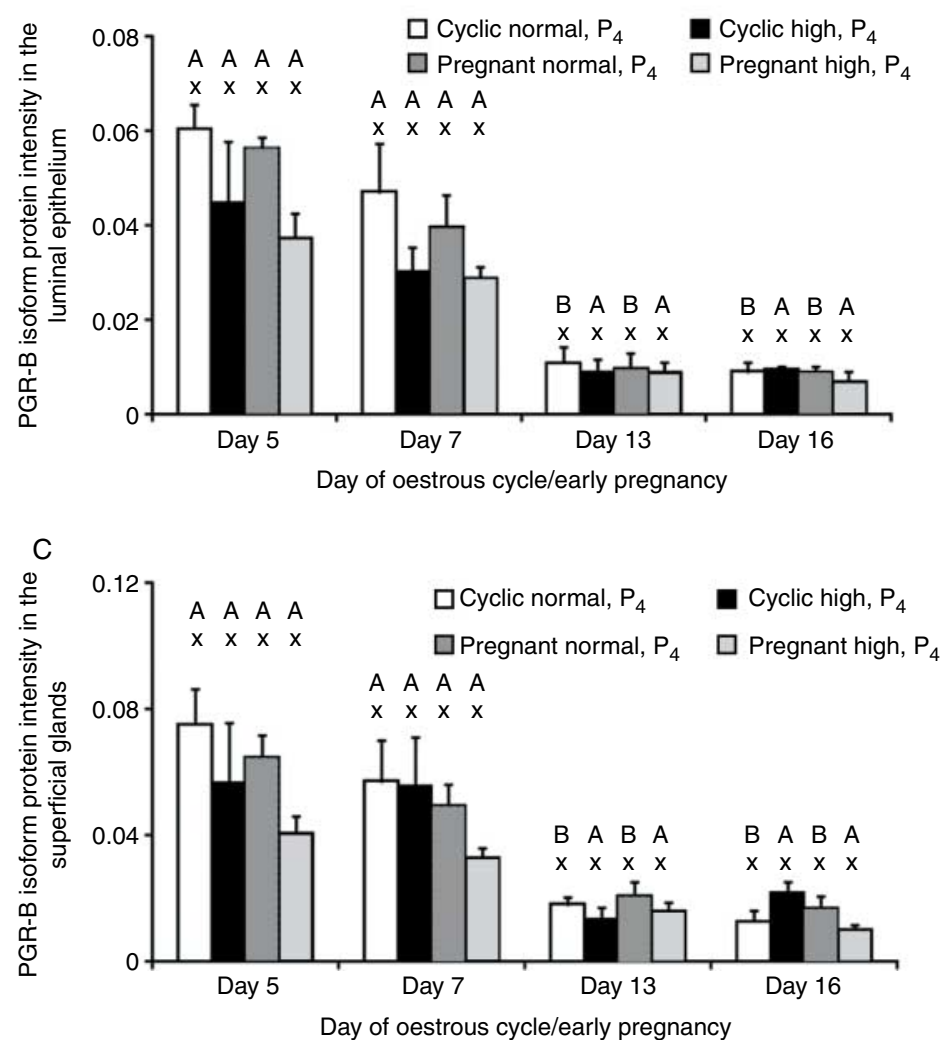

Figure 3 Representative images depicting the localisation of PGR-B protein isoform (A) in the luminal epithelium (LE), superficial glands (SGs) and stroma (STR) of bovine endometrium on days $5,7,13$ and 16 in pregnant heifers with normal $(\mathrm{PN})$ or high $(\mathrm{PH}) \mathrm{P}_{4}$. Bar $=100 \mu \mathrm{m}$. Graphical representation of the intensity of PGR-B protein isoform localised within the luminal epithelium (LE; B) or superficial glands (SGs; C) in uterine cross sections of cyclic and pregnant heifers with normal or high $\mathrm{P}_{4}$ on days $5,7,13$ and 16 of the oestrous cycle/early pregnancy. Significant differences $(P<0.05)$ in protein abundance are depicted with different superscripts between treatments within a specific day ( $\mathrm{x}$ and $\mathrm{y})$ and within treatment between days ( $A$ and $B$ ).

\section{Discussion}

$\mathrm{P}_{4}$ and $\mathrm{E}_{2}$ are important hormones in the regulation of the reproductive process in mammals. Not only are the concentrations of these hormones in peripheral blood important, but also their binding to specific nuclear receptors within target cells is critical for the biochemical action of $\mathrm{P}_{4}$ at cellular level. In this study, for the first time, the mRNA expression and protein localisation patterns of the ESRs and the nuclear PGRs during the bovine oestrous cycle have been characterised, and alterations in expression by the presence of a conceptus during early pregnancy and/or elevated $\mathrm{P}_{4}$ concentrations on their expression were determined. In this study, it has been shown that the tissue distribution of steroid receptors is regulated during the oestrous cycle and early pregnancy in a cell-specific manner, and that elevated $\mathrm{P}_{4}$ induces early downregulation of PGR, which is a critical event for the expression of genes required for conceptus development, maternal recognition of pregnancy and 
A

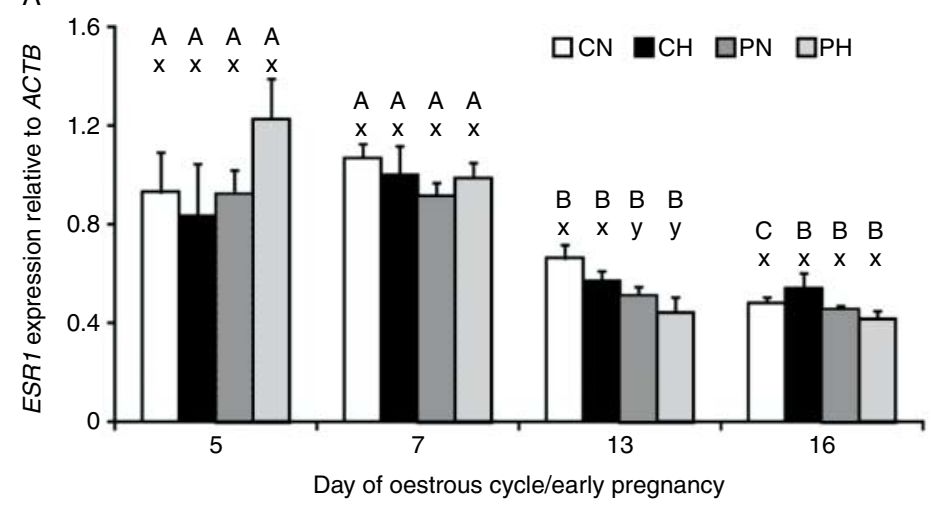

B

B Day
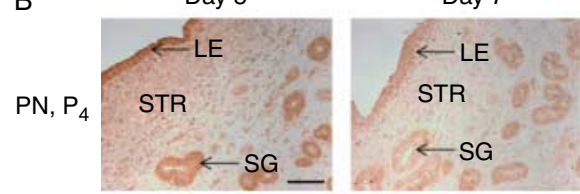

$\mathrm{PH}, \mathrm{P}_{4}$

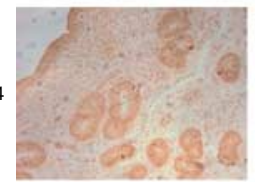

Negative control

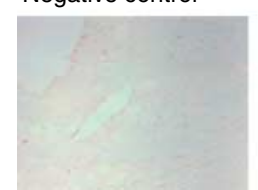

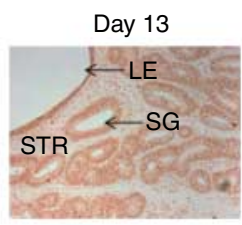
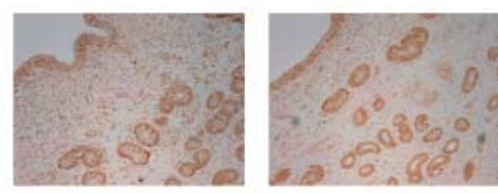

Figure 4 Temporal and spatial expressions of ESR1 mRNA relative to ACTB (normaliser gene) in bovine endometrium (A). Expression values are given for cyclic, normal $\mathrm{P}_{4}(\mathrm{CN}$; open bars); cyclic, high $\mathrm{P}_{4}\left(\mathrm{CH}\right.$; closed bars); pregnant, normal $\mathrm{P}_{4}$ (PN; dotted open bars); and pregnant, high $\mathrm{P}_{4}$ ( $\mathrm{PH}$; hatched closed bars) heifers on days 5, 7, 13 and 16 of the oestrous cycle/early pregnancy. Significant differences $(P<0.05)$ in ESR1 expression within specific treatments between days are denoted by $\mathrm{A}-\mathrm{C}$, while significant differences $(P<0.05)$ in ESR1 expression within each day amongst the treatments are denoted by $x$ and y. Representative images (B) depicting the localisation of ESR1 protein isoform in the luminal epithelium (LE), superficial glands (SGs) and stroma (STR) of bovine endometrium on days 5, 7 , 13 and 16 in pregnant heifers with normal (PN) or high $(\mathrm{PH}) \mathrm{P}_{4}$. Bar $=100 \mu \mathrm{m}$. implantation. In the current study, although the whole endometrial homogenate used for quantitative real-time (QRT-PCR) could not demonstrate the cell-specific changes in mRNA expression, localisation of the receptor proteins through immunohistochemistry (IHC) analysis made this possible.

$\mathrm{P}_{4}$ plays a key role in embryo/conceptus development and in the maintenance of pregnancy (McNeill et al. 2006, Satterfield et al. 2006). The PGR mRNA and protein expressions displayed similar temporal changes during the oestrous cycle/early pregnancy, and were consistent with other reports in cattle (Robinson et al. 2001) and sheep (Wathes \& Hamon 1993, Spencer \& Bazer 1995), with the highest expression being observed during the early luteal phase and lowest expression during the mid-late luteal phase (days 13 and 16). By day 16, PGR gene expression had begun increasing significantly in pregnant heifers. In this study, although PGR-AB was present at a much lower intensity than PGR-B, the pattern of expression for both proteins was similar, showing variation within specific cell types for specific days of oestrous cycle/early pregnancy. Highest expression of both PGR-AB and PGR-B proteins was found in heifers with normal $\mathrm{P}_{4}$ during the early luteal phase in agreement with previous findings in cattle (Kimmins \& MacLaren 2001, Robinson et al. 2001, Martin et al. 2008) and sheep (Spencer \& Bazer 1995); however, we have shown for the first time in cattle that high $\mathrm{P}_{4}$ advances the downregulation of its own receptor in the LE and SGs, further supporting the hypothesis that high $\mathrm{P}_{4}$ negatively regulates the expression of its own receptor. The intensity of both $\mathrm{PGR}-\mathrm{AB}$ and PGR-B proteins localised within the DGs, MYO and STR remained detectable throughout, with varying levels of expression. Despite the fact that $\mathrm{P}_{4}$ is critical for the establishment and maintenance of pregnancy, loss of the PGR from the endometrial epithelia is critical for the establishment of implantation (Bazer et al. 2009). In the current study, downregulation of PGR had occurred by day 13 consistent with previous findings (Spencer \& Bazer 1995, Kimmins \& MacLaren 2001), and coincides with the period of conceptus elongation, interferon $\tau$ secretion and maternal recognition of pregnancy (Spencer \& Bazer 1996). The loss of PGR in uterine epithelia appears to be a prerequisite for maternal recognition of pregnancy and conceptus development 


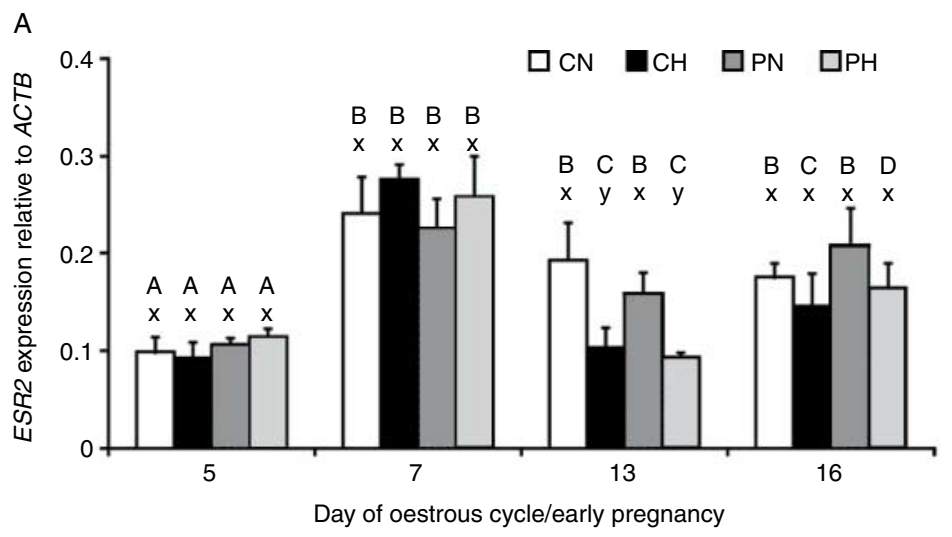

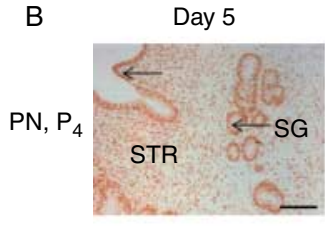
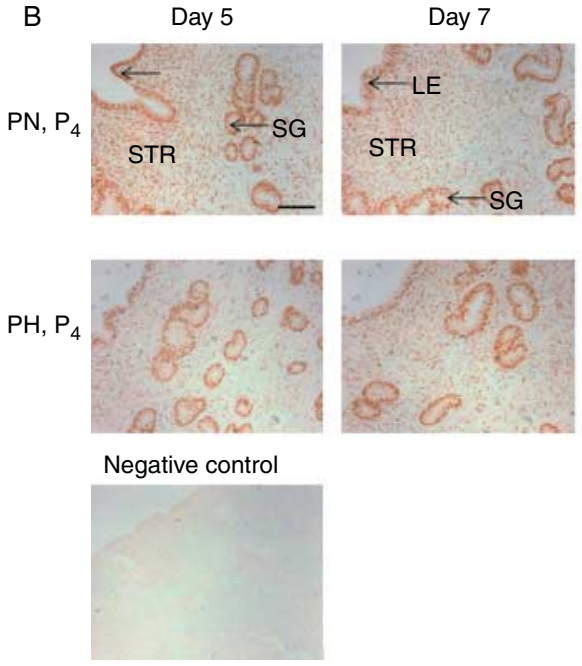
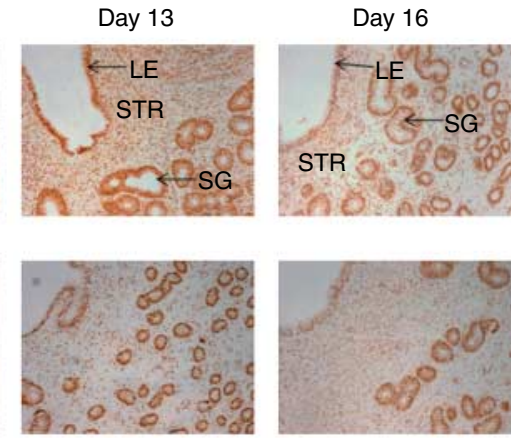

Day 16

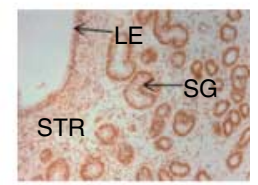

Figure 5 Temporal and spatial expressions of ESR2 mRNA relative to ACTB (normaliser gene) in bovine endometrium (A). Expression values are given for cyclic, normal $\mathrm{P}_{4}$ (CN; open bars); cyclic, high $\mathrm{P}_{4}\left(\mathrm{CH}\right.$; closed bars); pregnant, normal $\mathrm{P}_{4}$ (PN; dotted open bars); and pregnant, high $\mathrm{P}_{4}$ $(\mathrm{PH}$; hatched closed bars) heifers on days 5, 7, 13 and 16 of the oestrous cycle/early pregnancy. Significant differences $(P<0.05)$ in ESR2 expression within specific treatments between days are denoted by $\mathrm{A}-\mathrm{D}$, while significant differences $(P<0.05)$ in $E S R 2$ expression within each day amongst the treatments are denoted by $x$ and $y$. Representative images (B) depicting the localisation of ESR2 protein isoform in the luminal epithelium (LE), superficial glands (SGs) and stroma (STR) of bovine endometrium on days 5, 7, 13 and 16 in pregnant heifers with normal ( $\mathrm{PN}$ ) or high $(\mathrm{PH}) \mathrm{P}_{4}$. Bar $=100 \mu \mathrm{m}$. in early pregnancy (Spencer et al. 2008) as well as for epithelial cell proliferation and differentiated functions as directed by specific factors (progestamedins) produced by PGR-positive stromal cells (Bazer et al. 2009). While $\mathrm{P}_{4}$ supplementation beginning on day 3 had no significant effect on PGR mRNA expression, it had a profound effect on the expression of PGR protein on days 5 and 7 . The fact that the level of expression of PGR-AB in the high $\mathrm{P}_{4}$ group on day 5 was similar to the day 7 expression by the normal $\mathrm{P}_{4}$ heifers demonstrates that high $\mathrm{P}_{4}$ advanced the downregulation of PGR protein from mainly the LE. Low PGR expression in animals with elevated $\mathrm{P}_{4}$ has been observed in sheep (Satterfield et al. 2006), but it had not been studied previously in cattle. This downregulation of PGRs by elevated $\mathrm{P}_{4}$ during this critical window raises the questions of the mechanism of action by which elevated $\mathrm{P}_{4}$ on days $3-7$ subsequently is responsible for advanced conceptus elongation. High $\mathrm{P}_{4}$ concentrations have been shown to advance conceptus elongation in cattle (Mann et al. 2006, Carter et al. 2008) and sheep (Satterfield et al. 2006). Similarly, transfer of embryos to a uterus previously exposed to elevated $\mathrm{P}_{4}$ results in larger conceptuses on days 13 and 16 (Lonergan et al. 2007, Clemente et al. 2009). In addition, high $\mathrm{P}_{4}$ levels have also been associated with advancement of $\mathrm{P}_{4}$ actions in the uterus (McNeill et al. 2006, Forde et al. 2009). Drawing from these previously observed effects of high $\mathrm{P}_{4}$ and the results from this study, we hypothesise that early priming of the uterus by $\mathrm{P}_{4}$ through exogenous $\mathrm{P}_{4}$ supplementation leads to an advanced downregulation of PGR from the LE and subsequently the SGs, allowing for early regulation of $\mathrm{P}_{4}$-responsive genes in the uterus, that are geared towards advancing conceptus development and producing an optimum uterine environment for implantation. The $\mathrm{P}_{4}$ profiles in the animals used in the current study had been fully characterised in a previous study (Carter et al. 2008), and were found to be significantly higher in the high $\mathrm{P}_{4}$ groups than in the normal $\mathrm{P}_{4}$ groups from day 3.5 until day 7 , coincident with the time of decreased expression of PGR protein in the high $\mathrm{P}_{4}$ groups. Thereafter, the $\mathrm{P}_{4}$ concentration between the high and normal $\mathrm{P}_{4}$ groups tended to merge (Carter et al. 2008). High levels of PGR protein are expressed during the early 
luteal phase of the cycle, when $\mathrm{P}_{4}$ concentrations although increasing are still low, and therefore unable to inhibit the stimulatory effects of $E_{2}$ on the expression of not only PGR but also ESR1. However, continuous exposure of the endometrium to $\mathrm{P}_{4}$ for 8-10 days results in the downregulation of PGR from the endometrial LE and SGs (Spencer \& Bazer 1995). In spite of this, high $P_{4}$ concentrations are still maintained until the late luteal phase when the luteolytic mechanism is activated in cyclic animals (Spencer \& Bazer 1995). The luteal phase is said to be sustained by the action of progestamedins on the PGR-negative cells (Spencer \& Bazer 1995, Bazer et al. 2008). These progestamedins, such as the $\mathrm{P}_{4}$-responsive fibroblast growth factors, are produced by uterine stromal cells, which still maintain PGR expression even after downregulation of PGR from LE and SGs has occurred (Spencer \& Bazer 1995, Bazer et al. 2008).

$E_{2}$ is the other key steroid reproductive hormone, but its function relates more to stimulation of motility and secretory activity of the tract than to conceptus physiology (Spencer \& Bazer 1995). The expression of ESR 1 only differed between days 7 and 13, with a decrease in expression being maintained during the late luteal phase, which reflects the pattern described in previous studies in cattle and sheep (Wathes \& Hamon 1993, Spencer \& Bazer 1995, Robinson et al. 2001). This pattern of ESR1 expression mimics circulating concentrations of $\mathrm{E}_{2}$ during the oestrous cycle (Sunderland et al. 1994). The $E_{2}$ concentrations are significantly elevated on days 3-6 from the first dominant follicle, but are not elevated from the second dominant follicle due to luteal phase $\mathrm{P}_{4}$ concentrations suppressing LH pulse frequency during the late luteal phase of the oestrous cycle/early pregnancy. Although there was similar expression for ESR 1 on days 5, 7 and 16 across all treatments, on day 13 in the current study, pregnant heifers had lower ESR1 expression than cyclic heifers. This is in contrast to earlier reports that found similar expression of the gene throughout the oestrous cycle and early pregnancy (Wathes \& Hamon 1993, Spencer \& Bazer 1995, Robinson et al. 2001). A previous inconsistency in the expression of ESR1 between the cyclic and pregnant groups on day 16 was suggested to be due to a difference in the length of the cycle between the animals used (Robinson et al. 2001). Another study (McNeill et al. 2006) found $\mathrm{P}_{4}$ supplementation to increase ESR1 expression on day 6 , and proposed it to be due to advancement of $\mathrm{P}_{4}$ actions. This report contrasts with our current findings, in which $\mathrm{P}_{4}$ supplementation had no significant effect on the expression of either $P G R$ or ESR1 mRNA. From the current results, we suggest that the consequence of these advanced effects of high $\mathrm{P}_{4}$ on ESR1 may at the level of translation lead to increased ESR1 protein due to a shortened cycle, perhaps pointing towards a faster development of the luteolytic mechanism as $E_{2}$ is partially luteolytic in late dioestrus (Spencer \& Bazer 1995). This is further supported by similar expression levels of ESR1 mRNA in the cyclic and pregnant heifers with high and normal $\mathrm{P}_{4}$ treatments.

Throughout the period from day 5 to 16 , the level of ESR2 in the current study was lower than that of ESR1. In fact, the lowest recorded level of ESR1 was still greater than the highest recorded level of ESR2. In rat uteri, ESR2 levels were also found to be much lower than ESR1 levels (Shughrue et al. 1998, Wang et al. 1999, Weihua et al. 2000), in spite of the uterus being a major oestrogen target tissue (Weihua et al. 2000). It has been suggested that ESR1 protein is more important than ESR2 protein for mediating oestrogen actions in the uterus (Pelletier et al. 2000). Although it has been reported previously in other species that both ESR subtypes have similar expression patterns for both mRNA and protein, differing only in the intensity of expression (Matsuzaki et al. 1999, Wang et al. 2000), the results obtained in this study show for the first time that in the bovine uterus, ESR 1 and ESR2 mRNAs have different expression patterns during the oestrous cycle/early pregnancy. The actual role and mechanism of action of ESR2 within the reproductive tract as well as the role that both oestrogen and $\mathrm{P}_{4}$ may play in its regulation are unknown (Wang et al. 2000). However, reduced fertility in ESR2 knockout female mice was associated with a likely loss of function of ESR2 gene (Kuiper et al. 1997, Wang et al. 2000). In the current study, ESR2 mRNA expression exhibited temporal regulation. Levels significantly increased on day 7 across all treatments. Previous studies in rats showed no association between the circulating hormone levels during the oestrous cycle and expression of either ESR2 mRNA or ESR2 protein in the uterus (Wang et al. 2000, Weihua et al. 2000). The current results indicate that in cattle, ESR2 may be responsive to the stimulatory effects of $E_{2}$ from a non-ovulatory follicle. Furthermore, results indicate that the normal physiological concentration of luteal $\mathrm{P}_{4}$ has no modulatory effect on the expression of ESR2 in the bovine uterus, further emphasising its lesser role in the tissue as has been suggested previously (Shughrue et al. 1998, Wang et al. 1999, 2000). Although expression of ESR2 protein in the bovine uterus was higher than that found in other species, its expression pattern was similar to that of other species described previously and was unaffected by the stage of the cycle (Saji et al. 2000, Wang et al. 2000).

In conclusion, the current results characterise both ESR and PGR mRNA levels and protein within specific cell types in the uterus, and show that they are temporally regulated during the oestrous cycle and early pregnancy. For the first time, we have shown that high $\mathrm{P}_{4}$ concentrations do not affect the expression of $P G R$ or ESR1 mRNA, but did decrease ESR2 mRNA expression. Moreover, we have demonstrated for the first time that elevated $\mathrm{P}_{4}$ from days $3-7$ of the oestrous 
cycle/early pregnancy advances the downregulation of the nuclear PGR in the LE, a key regulator of endometrial gene expression, which contributes, in part, to advanced conceptus development in cattle.

\section{Materials and Methods}

\section{Animal model and tissue collection}

Unless otherwise stated, all chemicals and reagents were sourced from Sigma. All experimental procedures involving animals were licensed by the Department of Health and Children, Ireland, in accordance with the Cruelty to Animals Act (Ireland 1897) and European Community Directive 86/609/EC, and sanctioned by the Animal Research Ethics Committee of University College Dublin. The experimental design was as described previously (Carter et al. 2008). In summary, the oestrous cycles of 263 heifers were synchronised using a controlled internal drug-releasing (CIDR, $1.94 \mathrm{~g} \mathrm{P}_{4}$ ) device (InterAg, Hamilton, New Zealand), which remained in the vagina for 8 days. Three days prior to CIDR device removal, all heifers received an injection of $2 \mathrm{ml}$ of a prostaglandin $\mathrm{F}_{2 \alpha}$ analogue (Estrumate, Schering-Plough Animal Health, Hertfordshire, UK; equivalent to $0.5 \mathrm{mg}$ cloprostenol) i.m. Of the 210 heifers that displayed standing oestrus within a narrow time window, 140 were artificially inseminated with semen to generate a pregnant group, while the remaining heifers were left as a non-inseminated cyclic control group. On day 3 of the oestrous cycle/early pregnancy, half of each group were randomly assigned to receive a $\mathrm{P}_{4}$-releasing intravaginal device (1.55 g P 4 : CEVA, Animal Health Ltd, Chesham, UK) to elevate circulating concentrations of $\mathrm{P}_{4}$ (Carter et al. 2008). This resulted in four treatment groups: i) pregnant, high $\mathrm{P}_{4}(\mathrm{PH})$; ii) pregnant, normal $\mathrm{P}_{4}(\mathrm{PN})$; iii) cyclic, high $\mathrm{P}_{4}(\mathrm{CH})$ and iv) cyclic, normal $\mathrm{P}_{4}(\mathrm{CN})$. The heifers were then randomly assigned for slaughter on either day 5, 7, 13 or 16 of the oestrous cycle or early pregnancy. Within $30 \mathrm{~min}$ of slaughter, the reproductive tracts of all heifers were retrieved and flushed with $20 \mathrm{ml}$ of PBS containing $10 \%$ FCS. In relation to the inseminated heifers, only tissues from those with an appropriately developed embryo/conceptus for the day of pregnancy were further processed. Thus, for each treatment, five animals were collected per time point (i.e. 4 treatments $\times 4$ days $\times 5$ animals $=$ a total of 80 animals). Approximately one $25-\mathrm{mm}$ whole cross section of the uterine horn ipsilateral to the corpus luteum was fixed for $24 \mathrm{~h}$ in $10 \%$ buffered formalin for IHC analysis. Samples for IHC analysis were then processed by dehydration through a series of ascending concentrations of alcohol, cleared in xylene and finally impregnated with paraffin wax prior to sectioning for IHC analysis. Strips of endometrial tissue ( $\sim 300 \mathrm{mg}$ in weight) were removed from the mid-section of the ipsilateral horn, and were immersed in 1:5 w/v RNAlater and transported back to the laboratory on ice for QRT-PCR analysis. Samples for QRT-PCR were stored at $4{ }^{\circ} \mathrm{C}$ for $24 \mathrm{~h}$, excess RNAlater was removed and placed into a new tube and stored at $-80^{\circ} \mathrm{C}$ prior to RNA extraction.

\section{Quantitative real-time PCR}

Changes in gene expression were analysed using QRT-PCR as described previously (Forde et al. 2009). Briefly, 100-mg samples of ipsilateral endometrium were homogenised and total RNA was extracted using Trizol reagent (Invitrogen) as per the manufacturer's instructions. On-column DNase digestion and RNA cleanup were performed using a Qiagen mini kit (Qiagen). Both quality and quantity of the RNA were determined using the Agilent bioanalyser (Agilent Technologies, Santa Clara, CA, USA). cDNA was synthesised from $5 \mu \mathrm{g}$ of total RNA using Superscript III (Invitrogen) and random hexamers as per the manufacturer's instructions. All primers were designed using Primer Express Software (Applied Biosystems, Foster City, CA, USA) and manufactured by Eurofins MWG (Ebersberg, Germany). All reactions were performed using $50 \mathrm{ng}$ of CDNA, $10 \mu \mathrm{l}$ of SYBR Green Master Mix (Applied Biosystems) and primers at the optimised concentrations (Table 1). $\beta$-Actin (ACTB) was used as the normaliser gene, as determined by previous optimisation in this sample set (Forde et al. 2009). Final reaction volumes were made up to a total volume of $20 \mu \mathrm{l}$ with RNAse DNase-free $\mathrm{H}_{2} \mathrm{O}$. All QRT-PCRs were carried out in duplicate on the 7500 Fast RT-PCR System (Applied Biosystems). The cycling conditions were $50{ }^{\circ} \mathrm{C}$ for $2 \mathrm{~min}, 95^{\circ} \mathrm{C}$ for $10 \mathrm{~min}, 40-95{ }^{\circ} \mathrm{C}$ cycles for $15 \mathrm{~s}$ each and $60^{\circ} \mathrm{C}$ for $1 \mathrm{~min}$. Inclusion of a dissociation curve in each QRT-PCR run ensured specificity of the amplicons.

\section{Immunohistochemistry of ESR1, ESR2, PGR-AB and PGR-B}

Protein localisation and intensity were determined using IHC analysis, using a previously described procedure (Van den Broeck et al. 2002), which we optimised to suit the current

Table 1 Accession numbers and symbols of genes used to generate primer pair sequences ( $5^{\prime}$ to $3^{\prime}$ direction) and primer concentrations (conc.) as used in quantitative real-time-PCR.

\begin{tabular}{lllll}
\hline $\begin{array}{l}\text { Accession } \\
\text { number }\end{array}$ & $\begin{array}{l}\text { Gene } \\
\text { symbol }\end{array}$ & Gene name & Forward primer & Reverse primer \\
\hline $\begin{array}{l}\text { AV607592 } \\
\text { XM_583951.3 }\end{array}$ & $\begin{array}{l}\text { ACTB } \\
P G R\end{array}$ & $\begin{array}{l}\text { Actin, } \beta \\
\text { Predicted: Bos taurus } \\
\text { progesterone } \\
\text { receptor, mRNA }\end{array}$ & $\begin{array}{l}\text { CGCCATGGATGATGATATTGC } \\
\text { GAGAGCTCATCAAGGCAATTGG }\end{array}$ & $\begin{array}{l}\text { AAGCCGGCCTTGCACAT } \\
\text { CACCATCCCTGCCATATCTTG }\end{array}$ \\
NM_001001443 & ESR1 & $\begin{array}{r}\text { Bourus oestrogen } \\
\text { receptor } 1, \text { mRNA } \\
\text { Bos taurus oestrogen } \\
\text { receptor 2, mRNA }\end{array}$ & CCTCTCTCACTTCAGGCACA & ATCTCCAGCAGCAGGTCGTA \\
NM_174051.3 & ESR2 & GGTCAATCCATCCTACCCCT & TTCACGCCAAGGACTCTTTT \\
\hline
\end{tabular}


Table 2 Primary antibody sources and dilutions used for the localisation of receptor proteins in immunohistochemistry.

\begin{tabular}{llcl}
\hline $\begin{array}{l}\text { Primary antibody } \\
\text { symbol }\end{array}$ & Name & Dilution & Incubation \\
\hline PGR-AB & Mouse MAB, progesterone receptor Ab-8 (Clone hPRa 2+hPRa 3) & $1: 250$ & $4^{\circ} \mathrm{C}$ overnight \\
PGR-B & Mouse MAB, progesterone receptor Ab-2 (Clone hPRa 2) & $1: 200$ & $4^{\circ} \mathrm{C}$ overnight \\
ESR1 & Rabbit polyclonal antibody, oestrogen receptor Ab-17 & $1: 50$ & 40 min at room temperature \\
ESR2 & Monoclonal mouse anti-human oestrogen receptor $\beta 1$ & $1: 50$ & $4^{\circ} \mathrm{C}$ overnight \\
\hline
\end{tabular}

experiment. Unless otherwise stated, all washes were done twice in $0.05 \mathrm{M}$ Tris-buffered saline (TBS; $\mathrm{pH} 7.7$ ) for $5 \mathrm{~min}$ each, and all incubations were carried out in a humid chamber at room temperature. Four micron-thick sections of whole uterine tissue were cut from the paraffin-embedded tissue blocks, mounted on glass slides coated with $98 \%$ 3-aminopropyl triethoxysilane and dried overnight at $56{ }^{\circ} \mathrm{C}$. One block per animal was stained, and there were five animals per treatment per time point as outlined above. From each block (i.e. animal), 15 sections were taken; from amongst these 15 sections, sections were chosen at random for testing the various antibodies. Two negative control slides (where the primary antibody was omitted) and a pre-determined positive control slide were also included in each assay.

Slides were deparaffinised by two washes in xylene and rehydrated through a series of graded alcohol steps (100 and $70 \%$ ). Antigen retrieval was achieved by heating the slides in $0.01 \mathrm{M}$ sodium citrate buffer (May \& Baker Ltd, Essex, UK) at a $\mathrm{pH}$ of 6.0 for $20 \mathrm{~min}$, and subsequent cooling for a further $20 \mathrm{~min}$.

Endogenous peroxidase activity was neutralised by incubating the slides for 30 min with $1 \%$ hydrogen peroxide in methanol. Non-specific binding was inhibited by incubating the slides for 30 min with $2 \%$ of either normal rabbit serum (for both PGR (Laboratory Instruments and Service Centre, Ashbourne, Co., Meath, Ireland) and ESR2 (Dako Diagnostics, Cambridgeshire, UK) antibodies) or goat serum (for ESR1 antibody: Laboratory Instruments and Service Centre) in $0.05 \mathrm{M}$ TBS (v/v). Primary antibodies (ESR1, PGR-AB and PGR-B sourced from Laboratory Instruments and Service Centre; and ESR2 sourced from Dako Diagnostics) were incubated at the appropriate dilution and under optimum conditions (Table 2). Slides were then washed and incubated for $45 \mathrm{~min}$ with the polyclonal biotinylated secondary antibodies, which was a rabbit anti-mouse at a 1:100 dilution (for PGR-AB, PGR-B and ESR2) and a goat anti-rabbit at a 1:300 dilution (for ESR1; Dako Diagnostics). The slides were washed, and avidin-biotin-HRP complex (Vectastain Elite ABC Kit, Vector Labs, Peterborough, UK) was added to the slides and they were incubated for $30 \mathrm{~min}$. Following further washing, $3,3^{\prime}$-diaminobenzidine tetrahydrochloride chromogen substrate was added to the slides, and they were incubated for $10 \mathrm{~min}$. The above-mentioned reaction was stopped by flushing the slides with distilled water, and the slides were then washed under running tap water for $7 \mathrm{~min}$. This was followed by dehydration using increasing concentrations of alcohol (70 and $100 \%$ ) for $5 \mathrm{~min}$ each and subsequent clearing in two successive changes of xylene for 10 min each. Slides were mounted using DPX (AGB Scientific Ltd, Dublin, Ireland) and observed under $10 \times$ magnification. Using a digital camera, four images were captured per tissue section (two images showing the LE, SGs and STR, and two images showing the DGs and MYO). Intensity of staining for all the regions was determined using Image-Pro Plus software (version 6.2, MediaCybernetics, Bethesda, MD, USA).

\section{Statistical analyses}

Differences in mRNA expression values were determined using the $\Delta C_{\mathrm{t}}$ method, with expression for each gene generated relative to $A C T B$. Student's $t$-test was performed to determine significant differences in expression values for each gene of interest within treatments, across time points and within time points between treatments. All analyses for determining the effect of treatment on the intensity of localised protein were done using SAS (SAS Institute Inc., Cary, NC, USA). Parameters were checked for the assumptions underlying the ANOVA using PROC UNIVARIATE. Parameters that violated these assumptions were transformed using the appropriate $\lambda$ value obtained from PROC TRANSREG. Analyses were done using PROC MIXED with day, pregnancy status, $\mathrm{P}_{4}$ treatment and their three-way interaction as the main effects. The graphs show the least square means and their S.E.M.

\section{Declaration of interest}

The authors declare that there is no conflict of interest that could be perceived as prejudicing the impartiality of the research reported.

\section{Funding}

This work was funded by Science Foundation Ireland PI grant 06/INI/B62.

\section{Acknowledgements}

The authors express gratitude to all the principal investigators, post-doctoral scientists, technical staff and all graduate students involved in the sample collection and assays as well as for their advice on various aspects of the study.

\section{References}

Arnett-Mansfield RL, DeFazio A, Mote PA \& Clarke CL 2004 Subnuclear distribution of progesterone receptors $A$ and $B$ in normal and malignant endometrium. Journal of Clinical Endocrinology and Metabolism 89 1429-1442. 
Bazer FW, Burghardt RC, Johnson GA, Spencer TE \& Wu G 2008 Interferons and progesterone for establishment and maintenance of pregnancy: interactions among novel cell signaling pathways. Reproductive Biology 8 179-211.

Bazer FW, Spencer TE, Johnson GA, Burghardt RC \& Wu G 2009 Comparative aspects of implantation. Reproduction 138 195-209.

Carson-Jurica MA, Schrader WT \& O'Malley BW 1990 Steroid receptor family: structure and functions. Endocrine Reviews 11 201-220.

Carter F, Forde N, Duffy P, Wade M, Fair T, Crowe MA, Evans AC, Kenny DA, Roche JF \& Lonergan P 2008 Effect of increasing progesterone concentration from day 3 of pregnancy on subsequent embryo survival and development in beef heifers. Reproduction, Fertility, and Development 20 368-375.

Clemente M, de La Fuente J, Fair T, Al Naib A, Gutierrez-Adan A, Roche JF, Rizos D \& Lonergan P 2009 Progesterone and conceptus elongation in cattle: a direct effect on the embryo or an indirect effect via the endometrium? Reproduction 138 507-517.

De M \& Wood GW 1990 Influence of oestrogen and progesterone on macrophage distribution in the mouse uterus. Journal of Endocrinology 126 417-424.

D'Haeseleer M, Cornillie P, Simoens P \& van den Broeck W 2006 Localization of oestrogen receptors within various bovine ovarian cell types at different stages of the oestrous cycle. Anatomia, Histologia, Embryologia 35 334-342.

Enmark E, Pelto-Huikko M, Grandien K, Lagercrantz S, Lagercrantz J, Fried G, Nordenskjold M \& Gustafsson JA 1997 Human estrogen receptor $\beta$-gene structure, chromosomal localization, and expression pattern. Journal of Clinical Endocrinology and Metabolism 82 4258-4265.

Forde N, Carter F, Fair T, Crowe MA, Evans AC, Spencer TE, Bazer FW, McBride R, Boland MP, O'Gaora P et al. 2009 Progesteroneregulated changes in endometrial gene expression contribute to advanced conceptus development in cattle. Biology of Reproduction 81 784-794.

Garrett JE, Geisert RD, Zavy MT \& Morgan GL 1988 Evidence for maternal regulation of early conceptus growth and development in beef cattle. Journal of Reproduction and Fertility 84 437-446.

Geisert RD, Fox TC, Morgan GL, Wells ME, Wettemann RP \& Zavy MT 1991 Survival of bovine embryos transferred to progesterone-treated asynchronous recipients. Journal of Reproduction and Fertility 92 475-482.

Ing NH \& Tornesi MB 1997 Estradiol up-regulates estrogen receptor and progesterone receptor gene expression in specific ovine uterine cells. Biology of Reproduction 56 1205-1215.

Kachkache M, Acker GM, Chaouat G, Noun A \& Garabedian M 1991 Hormonal and local factors control the immunohistochemical distribution of immunocytes in the rat uterus before conceptus implantation: effects of ovariectomy, fallopian tube section, and injection. Biology of Reproduction 45 860-868.

Kimmins S \& MacLaren LA 2001 Oestrous cycle and pregnancy effects on the distribution of oestrogen and progesterone receptors in bovine endometrium. Placenta 22 742-748.

Kuiper GG, Enmark E, Pelto-Huikko M, Nilsson S \& Gustafsson JA 1996 Cloning of a novel receptor expressed in rat prostate and ovary. PNAS 93 5925-5930.

Kuiper GG, Carlsson B, Grandien K, Enmark E, Haggblad J, Nilsson S \& Gustafsson JA 1997 Comparison of the ligand binding specificity and transcript tissue distribution of estrogen receptors $\alpha$ and $\beta$. Endocrinology 138 863-870.

Lonergan P, Woods A, Fair T, Carter F, Rizos D, Ward F, Quinn K \& Evans A 2007 Effect of embryo source and recipient progesterone environment on embryo development in cattle. Reproduction, Fertility, and Development 19 861-868.

Mann GE, Fray MD \& Lamming GE 2006 Effects of time of progesterone supplementation on embryo development and interferon-tau production in the cow. Veterinary Journal 171 500-503.

Martin I, Torres Neto R, Oba E, Buratini J Jr, Binelli M, Laufer-Amorim R \& Ferreira JC 2008 Immunohistochemical detection of receptors for oestrogen and progesterone in endometrial glands and stroma during the oestrous cycle in Nelore (Bos taurus indicus) cows. Reproduction in Domestic Animals 43 415-421.
Matsuzaki S, Fukaya T, Suzuki T, Murakami T, Sasano H \& Yajima A 1999 Oestrogen receptor $\alpha$ and $\beta$ mRNA expression in human endometrium throughout the menstrual cycle. Molecular Human Reproduction $\mathbf{5}$ 559-564.

McNeill RE, Sreenan JM, Diskin MG, Cairns MT, Fitzpatrick R, Smith TJ \& Morris DG 2006 Effect of systemic progesterone concentration on the expression of progesterone-responsive genes in the bovine endometrium during the early luteal phase. Reproduction, Fertility, and Development 18 573-583.

Mote PA, Arnett-Mansfield RL, Gava N, deFazio A, Mulac-Jericevic B, Conneely OM \& Clarke CL 2006 Overlapping and distinct expression of progesterone receptors $\mathrm{A}$ and $\mathrm{B}$ in mouse uterus and mammary gland during the estrous cycle. Endocrinology 147 5503-5512.

Mulac-Jericevic B \& Conneely OM 2004 Reproductive tissue selective actions of progesterone receptors. Reproduction 128 139-146.

Mulac-Jericevic B, Mullinax RA, DeMayo FJ, Lydon JP \& Conneely OM 2000 Subgroup of reproductive functions of progesterone mediated by progesterone receptor-B isoform. Science 289 1751-1754.

Mulac-Jericevic B, Lydon JP, DeMayo FJ \& Conneely OM 2003 Defective mammary gland morphogenesis in mice lacking the progesterone receptor B isoform. PNAS 100 9744-9749.

Pelletier G, Labrie C \& Labrie F 2000 Localization of oestrogen receptor $\alpha$, oestrogen receptor $\beta$ and androgen receptors in the rat reproductive organs. Journal of Endocrinology 165 359-370.

Robinson RS, Mann GE, Lamming GE \& Wathes DC 2001 Expression of oxytocin, oestrogen and progesterone receptors in uterine biopsy samples throughout the oestrous cycle and early pregnancy in cows. Reproduction 122 965-979.

Saji S, Jensen EV, Nilsson S, Rylander T, Warner M \& Gustafsson JA 2000 Estrogen receptors $\alpha$ and $\beta$ in the rodent mammary gland. PNAS 97 337-342.

Satterfield MC, Bazer FW \& Spencer TE 2006 Progesterone regulation of preimplantation conceptus growth and galectin 15 (LGALS15) in the ovine uterus. Biology of Reproduction 75 289-296.

Shughrue PJ, Lane MV, Scrimo PJ \& Merchenthaler I 1998 Comparative distribution of estrogen receptor- $[\alpha](\operatorname{ER}-[\alpha])$ and $[\beta](E R-[\beta]) m R N A$ in the rat pituitary, gonad, and reproductive tract. Steroids 63 498-504.

Spencer TE \& Bazer FW 1995 Temporal and spatial alterations in uterine estrogen receptor and progesterone receptor gene expression during the estrous cycle and early pregnancy in the ewe. Biology of Reproduction 53 1527-1543.

Spencer TE \& Bazer FW 1996 Ovine interferon tau suppresses transcription of the estrogen receptor and oxytocin receptor genes in the ovine endometrium. Endocrinology 137 1144-1147.

Spencer TE, Becker WC, George P, Mirando MA, Ogle TF \& Bazer FW 1995 Ovine interferon-tau regulates expression of endometrial receptors for estrogen and oxytocin but not progesterone. Biology of Reproduction $\mathbf{5 3}$ 732-745.

Spencer TE, Sandra O \& Wolf E 2008 Genes involved in conceptusendometrial interactions in ruminants: insights from reductionism and thoughts on holistic approaches. Reproduction 135 165-179.

Stormshak F \& Bishop CV 2008 Board-invited review: estrogen and progesterone signaling: genomic and nongenomic actions in domestic ruminants. Journal of Animal Science 86 299-315.

Sunderland SJ, Crowe MA, Boland MP, Roche JF \& Ireland JJ 1994 Selection, dominance and atresia of follicles during the oestrous cycle of heifers. Journal of Reproduction and Fertility 101 547-555.

Tibbetts TA, Conneely OM \& O'Malley BW 1999 Progesterone via its receptor antagonizes the pro-inflammatory activity of estrogen in the mouse uterus. Biology of Reproduction 60 1158-1165.

Tsai MJ \& O'Malley BW 1994 Molecular mechanisms of action of steroid/thyroid receptor superfamily members. Annual Review of Biochemistry 63 451-486.

Van den Broeck W, D'Haeseleer M, Coryn M \& Simoens P 2002 Cellspecific distribution of progesterone receptors in the bovine ovary. Reproduction in Domestic Animals 37 314-320.

Wang H, Masironi B, Eriksson H \& Sahlin L 1999 A comparative study of estrogen receptors $\alpha$ and $\beta$ in the rat uterus. Biology of Reproduction 61 955-964.

Wang H, Eriksson $\mathbf{H}$ \& Sahlin L 2000 Estrogen receptors $\alpha$ and $\beta$ in the female reproductive tract of the rat during the estrous cycle. Biology of Reproduction 63 1331-1340. 
Wathes DC \& Hamon M 1993 Localization of oestradiol, progesterone and oxytocin receptors in the uterus during the oestrous cycle and early pregnancy of the ewe. Journal of Endocrinology 138 479-492.

Wathes DC, Mann GE, Payne JH, Riley PR, Stevenson KR \& Lamming GE 1996 Regulation of oxytocin, oestradiol and progesterone receptor concentrations in different uterine regions by oestradiol, progesterone and oxytocin in ovariectomized ewes. Journal of Endocrinology 151 375-393.
Weihua Z, Saji S, Makinen S, Cheng G, Jensen EV, Warner M \& Gustafsson JA 2000 Estrogen receptor (ER) $\beta$, a modulator of $E R \alpha$ in the uterus. PNAS 97 5936-5941.

Received 1 March 2010

First decision 31 March 2010

Accepted 19 April 2010 